\title{
Organizational commitment and users' perception of ease of use: a study among bank managers
}

\author{
Joseph Vella \\ Department of Business Administration, Lulea University of Technology, \\ Luleå, Sweden \\ Albert Caruana \\ Department of Marketing, University of Malta, Msida, Malta, and \\ Leyland Pitt \\ Segal Graduate School of Business, Simon Fraser University, \\ Vancouver, Canada
}

Perception of ease of use

351

Received May 2011

Revised July 2011

Accepted September 2011

\begin{abstract}
Purpose - The purpose of this paper is to look at the issue of perceived ease of use of a web-based customer relationship management system and consider the role of organizational commitment as a possible antecedent.

Design/methodology/approach - Data for this study were collected from among managers of a major player in the community banking sector within the EU. A total of 274 valid responses were obtained from 398 managers.

Findings - Results have been mixed and partially conditioned by service providers' willingness to leverage the possibilities that the technology can provide.

Research limitations/implications - The study was limited to a single organization and consequently the results should be generalized with caution. Replication studies with improved measures, in other countries and contexts are desirable.

Practical implications - The results can be useful for management, since Web-based customer relationship management systems have been adopted by many service providers in their quest to offer better one-to-one marketing possibilities to their customers.

Originality/value - This paper demonstrates the importance of fostering a sense of organizational commitment amongst key service providers, as this in turn seems to enable them to overcome many impediments pertaining to technology use.
\end{abstract}

Keywords Internet, Customer relationship management, Community banking, Managers,

Normative commitment, Affective commitment, Continuance commitment, Perceived ease of use,

Technology acceptance, Technology use

Paper type Research paper

\section{Introduction}

There is little doubt that over the past two decades the internet along with other computer technologies has changed the way that business is conducted. While these technological advances have given manufacturers and service providers the possibility to reach out to many potential customers, it has also provided them with a fast and feasible way to target these customers individually (Chen and Popovich, 2003). Because organizations are finding it increasingly difficult to maintain product and cost advantages resulting solely from technology development, many have sought differentiation by leveraging the one-to-one marketing possibilities that technology is increasingly making available (Kimiloglu and Zarali, 2009). Organizations that treat their customers simply as end users of their products or services are deemed to be less

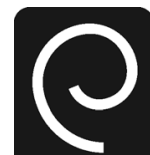

Emerald

Journal of Management Development

Vol. 32 No. 4, 2013 pp. $351-362$

(C) Emerald Group Publishing Limited 0262-1711

DOI 10.1108/02621711311326356 
$\mathrm{JMD}$

32,4

352 competitive than those that try to entice them into some form of mutual relationship (Schneider and Bowen, 1995). Thus a significant transformation in marketing practices from a transaction-oriented/product-focussed era to a relationship-oriented/ customer-focussed era has become a priority for organizations, in their ongoing drive to acquire and retain customers (Smith and Chang, 2010). The pioneering work on relationship marketing conducted by various researchers (e.g. Berry, 1983; Christopher et al., 1991; Grönroos, 1994; Jackson, 1985) has driven the development of customer relationship management (CRM) processes that include web-based applications (eCRM). These have sought to augment one-to-one marketing possibilities.

Over the past two decades the electronic era has redefined competitiveness. Contrary to many assumptions, technology advancement although necessary is not in itself sufficient to create a sustained competitive advantage (Carr, 2003). Rather it is the manner by which this technology is implemented and adopted that matters. This is because despite the potential benefits attributed to IT investments, the unwillingness of users to adopt technology can jeopardize the returns on these investments (Magni and Pennarola, 2005). Research has shown that perceived usefulness (PU) and perceived ease of use (PEOU) affect intended adoption of IT (Davis, 1989; Venkatesh, 2000; Venkatesh et al., 2003). PEOU has been shown to be a particularly important antecedent to systems adoption since "individuals are more likely to interact with a new technology if they perceive that relatively little effort is needed to interact with it" (Agarwal, 2000). Moreover, understanding the antecedents of PEOU from a theoretical standpoint is equally important because of its key role in determining users' acceptance and use (Liao and Tsou, 2009; Venkatesh and Davis, 1996). This paper builds on this argument by first looking at organizational commitment as a possible antecedent and proceeds to investigate whether this impacts employees' PEOU of technology. Although the presence of other antecedent variables, such as complexity of system, prior training and PU is acknowledged, the intention of this study is to emphasize the importance of organizational commitment as a potentially powerful antecedent that ultimately positively influences employees' behavior toward technology adoption. In this instance, managers' adoption of a bank's CRM system will be investigated to highlight such a relationship. Data are collected from managers at a community bank that operates a sophisticated eCRM system. Analysis is undertaken, conclusions are drawn, limitations are noted and other possible avenues for research are considered.

\section{Organizational commitment}

Organizational commitment is the bond linking individuals to their respective organizations and therefore held to be an important aspect of human resource management (Alper, 2008; Mathieu and Zajac, 1990). Organizational commitment can be described as the degree of responsibility that employees feel with respect to their organization's aims and objectives. It indicates the intensity of the psychological attachment between employees and their jobs.

Allen and Meyer (1996, p. 252) define organizational commitment as a "psychological link between the employee and his or her organization that makes it less likely that the employee will voluntarily leave the organization." The work undertaken by Meyer and Allen (Allen and Meyer, 1990, 1996; Meyer and Allen, 1984, 1991, 1997) has resulted in the development of a multi-component model of organizational commitment consisting of three "different frames of mind" which can characterize employees' commitment toward their respective organization. The three 
components are termed affective, continuance and normative commitment. Affective commitment takes place when employees' have a positive emotional attachment toward their organization. Typically, these employees would strongly concur with the goals of their organization and feel a strong sense of belonging to it. In such situations employees' commitment to their organization is purely voluntary. Continuance commitment on the other hand describes the situation whereby individuals commit to the organization mainly out of fear of the perceived high costs associated with forgoing their organizational membership (Allen and Meyer, 2000; Meyer et al., 2002). These costs would include both economic costs (such as retirement schemes) as well as social costs (such as peer relationships). Here, commitment is not voluntary; rather individuals feel compelled to commit themselves to avoid any potentially unpleasant consequences. Normative commitment occurs when individuals not only commit to their organization because of deep feelings of obligation (Meyer and Allen, 1991, 1997) but because they also feel that they must stay. These feelings may result from a sense of obligation toward the organization as a form of acknowledgement toward some form of interest or investment that the individual has received from the organization. For example, following intense training sessions; employees may feel that they must stay with their organization because they "ought to."

The three dimensions of the organization commitment construct are captured by the instrument developed by Allen and Meyer that has been shown to exhibit positive psychometric properties (Allen and Meyer, 1996; Meyer et al., 1993). In addition the organizational commitment construct has been linked to various antecedents and consequences as highlighted in the meta-analysis by Mathieu and Zajac (1990).

\section{PEOU}

The technology acceptance model (Davis, 1989; Davis et al., 1989) has been widely used to predict users' acceptance of information technology. In this model PU and PEOU are inherent users' beliefs that are crucial in determining their intention to adopt a particular technology (Moore and Benbasat, 1991; Venkatesh and Davis, 1996; Yousafzai et al., 2007). Although the significance of PEOU on intention to use seems to vary according to context, for example from quite insignificant, as in the case of the medical profession (Chau and $\mathrm{Hu}, 2002$ ) to very significant, as in the case of the accounting profession (Bedard et al., 2003; Pennington et al., 2006); the literature abounds with evidence of the significant effect of PEOU on usage intention, either directly or else indirectly via its effect on PU (e.g. Agarwal and Prasad, 1999; Davis et al., 1989; Hu et al., 1999; Jackson et al., 1997; Venkatesh, 1999, 2000; Venkatesh and Davis, 1996, 2000; Venkatesh and Morris, 2000).

Davis (1989, p. 320) defines PEOU as "the degree to which a person believes that using a particular system would be free of effort," thus it follows that in order to foster the acceptance and usage of technological systems, these must be perceived to be easy to learn and use. Information technologies that are easy to use are normally perceived to be less threatening to the individual (Moon and Kim, 2001). Furthermore, Agarwal (2000) argues that individuals are more likely to interact with a new technology if they perceive that relatively little effort is required to interact with it.

Businesses have squandered millions of dollars on unsuccessful system implementations (Hopkins and Kessler, 2002). Often users fail to adopt such systems because of their negative PEOU (Gefen and Straub, 2000). Therefore it is important to attempt to identify antecedents that may positively influence users' PEOU. Yet surprisingly little research appears to have actually been done on understanding the
Perception of ease of use

353 
JMD

32,4

354 antecedents and determinants of this important predictor of the intention to use construct (Torkzadeh and Lee, 2003; Venkatesh and Davis, 1996). Some notable exceptions include: Anandarajan et al. (2002) who argued that in less developed countries, PEOU depends on subjective norms; Ghorab (1997) found that the sophistication level of the applied technology affects PEOU; Davis et al. (1989) established that self-efficacy and procedural knowledge affect PEOU; while Karahanna and Straub (1999) found that physical accessibility directly affected PEOU; Nov and Ye (2008) established that resistance to change is a significant determinant of PEOU and Venkatesh (2000) identified computer self-efficacy, computer anxiety, computer playfulness and facilitating conditions as being key determinants of PEOU.

\section{Organizational commitment and PEOU}

Organizational behavior theory recognizes that relationships within the organization and among users of technology in an organization have a significant effect on the actions of individuals within organizations (Brief and Weiss, 2002). Several studies have attempted to investigate the behavioral consequences of organizational commitment beyond the traditional consequence of retention (Magni and Pennarola, 2008). Research has shown that affective and normative commitment, are key elements that promote championship as well as a sense of co-operation between peers (Choi, 2006). Moreover, affective and normative commitment, have also been shown to underpin employees' support for change initiatives (Armenakis and Bedeian, 1999). Magni and Pennarola (2008), argue that individuals with a high level of affective commitment tend to be willing to exert extra effort toward accepting change. They proceed to suggest that these individuals would go even further to endeavor to understand the aim of the technology that they are expected to adopt and would also be ready to exert even more effort to understand how to use it. Their findings provide support for a positive link between affective commitment and both PEOU and PU. However, the authors do not consider the effect of normative, continuance or overall organizational commitment.

Organizational commitment is all about employees' attachment to their organization and employees who are committed to their organization are more likely to be willing to "go the extra mile." This leads us to hypothesize that individuals who are highly committed to their organization would be positively disposed to the use of new technology and willing to strive to overcome any perceived difficulties associated with the usability of that technology, hence:

H1. A positive organizational commitment among service providers leads to higher PEOU of technology.

\section{Methodology}

This paper sets out to test the relationship between organizational commitment and PEOU of technology, among service managers at a community bank, where a sophisticated eCRM system has been installed. To accomplish this, a questionnaire consisting of two instruments to capture each of the constructs in the study, is employed. The first construct of organizational commitment, as conceptualized by Allen and Meyer (1990, 1996), was captured using the 24-item three-dimensional instrument made up of sub measures for each of affective, continuance and normative commitment. The second construct of PEOU was measured using the six-item unidimensional instrument employed by Davis (1989) and Davis et al. (1989). 
In addition the final questionnaire also captured seven classificatory variables dealing with gender, age, marital status, academic qualifications, whether both subject and his/her partner worked, tenure with the bank and finally, current position at the bank. All items making up the two constructs were measured using Likert-type, scales ranging from $1=$ strongly disagree to $7=$ strongly agree.

Initially, a number of industries were considered as possible entities for testing the relationship outlined in the hypothesis. These included insurance, retailing and community banking. In the end a major player in the community banking sector was chosen, mainly on the grounds that the majority of the respondents holding managerial positions within the bank could be accessed and generally acknowledged the usefulness of CRM systems. Moreover their bank had provided them with extensive training and they were therefore very familiar with the bank's CRM system. In addition the bank recognized that the human service element is a critical aspect to effective marketing and senior management was willing to provide support with the data collection. Finally, the bank possessed a national network of offices, an established brand name and could boast of a respectable market share of traditional deposits.

In order to ascertain that all the questions were fully coherent and understood, a pilot session was undertaken before dispatching the questionnaires to potential participants. To achieve this, a sample of ten managers was randomly selected from different offices of the bank and these were asked to complete the final questionnaire during a face-to-face meeting at their respective workplaces. We found no major problems associated with the questionnaire and only minor amendments were necessary. All managers at the bank were sent a covering letter explaining the nature of this research together with the self-completion questionnaire. The covering letter sought to assure respondents that complete anonymity would be respected. A total of 398 questionnaires were sent to all managers at the bank and 274 were collected after the cut-off date, four weeks later, representing an effective response rate of 68.8 percent.

\section{Analysis}

In total, 51.1 percent of respondents were female, with a mean age of 37.9 (SD 9.2); 74.3 percent were married and 73.2 percent indicated that both partners worked. In total, 53.1 percent of respondents had a graduate or a post-graduate degree and their average tenure with the bank was 17.2 years (SD 9.6). Descriptive statistics in terms of means and standard deviations for items used in the analysis appear in Table I. The factor structure of all the items that make up the two constructs was subject to a principal components factor analysis. Given the expected correlations among the dimensions and constructs this was followed by an oblimin rotation. During this phase and the subsequent testing for reliability using Cronbach's $\alpha$ 's it was necessary to delete five items, two from the eight items that make up the affective commitment dimension and three from the eight items that make up the normative commitment dimension. This deletion was required to eliminate items that loaded strongly on more than one factor or had item-to-total correlations with the other items making up the dimension that were rather low. The resultant loadings that appear in Table I, provide strong support for the factor structure of the two constructs and dimensions. They also provide support for the convergent and discriminant validity of the measures. The reliability for each of the constructs and dimensions are shown on the diagonal in Table II. All items exceed the 0.7 level and are therefore acceptable (Nunnally, 1967).

Items were summed up for each dimension and constructs and their values are shown in Table I. Following this an initial correlation among the composite variables
Perception of ease of use

355 


\begin{tabular}{lllllll}
\hline & \multicolumn{4}{c}{ Component } \\
& Mean & SD & 1 & 2 & 3 & 4 \\
\hline
\end{tabular}

I enjoy discussing my organization with people

outside it

I really feel as if this organization's problems are

356 my own

I feel that I am separated from the "rest of the family"

at my organization

I feel "emotionally distant" to this organization

This organization has a great deal of personal meaning for me

I feel strongly detached from my organization

Affective commitment

I feel very much at ease about what might happen

if I quit my job without having another one lined up

It would be very hard for me to leave my organization right now, even if I wanted to

Too much in my life would be disrupted if I decided I wanted to leave my organization now

I can afford to leave my organization now

Right now, staying with my organization is a matter of necessity as much as desire

I feel that I have too few options to consider leaving this organization

One of the few serious consequences of leaving this

organization would be the scarcity of available

alternatives

$\begin{array}{lll}5.22 & 1.42 & 0.74\end{array}$

$\begin{array}{lll}4.95 & 1.51 & 0.57\end{array}$

$\begin{array}{lll}4.83 & 1.59 & 0.59\end{array}$

$\begin{array}{lll}5.24 & 1.52 & 0.78\end{array}$

$\begin{array}{lll}5.03 & 1.44 & 0.67\end{array}$

$\begin{array}{lll}5.30 & 1.81 & 0.74\end{array}$

$30.57 \quad 6.06$

$\begin{array}{lll}5.01 & 2.03 & 0.31\end{array}$

$\begin{array}{lll}4.92 & 1.92 & 0.64\end{array}$

$\begin{array}{lll}4.99 & 1.80 & 0.67\end{array}$

$\begin{array}{lll}4.96 & 1.91 & 0.42\end{array}$

$\begin{array}{lll}4.64 & 1.73 \quad 0.61\end{array}$

$\begin{array}{lll}4.09 & 1.83 & 0.75\end{array}$

One of the major reasons I continue to work for this organization is that leaving would require considerable personal sacrifice - another organization may not match the overall benefits I have here

Continuous commitment

According to me it is perfectly ethical to jump from organization to organization

$4.24 \quad 1.86$

0.63

One of the major reasons I continue to work for this organization is that I believe that loyalty is important and therefore feel a sense of moral obligation to remain If 1 got another offer for a better job elsewhere I would feel it was wrong to leave my organization

I was taught to believe in the value of remaining loyal to one organization

Things were better in the days when people stayed with one organization for most of their careers Normative commitment Organizational commitment

The bank's CRM system has been easy to learn The bank's CRM system is clear and understandable

Table I.

Mean and standard deviation for items and principal component factor analysis with oblimin rotation
The bank's CRM system makes it easy for me to become skilful

The bank's CRM system is easy to use

The bank's CRM system helps is very controllable

The bank's CRM system is very flexible

Perceived ease of use $\begin{array}{ll}4.57 & 1.73\end{array}$

$37.43 \quad 8.78$

$4.37 \quad 1.72$

0.57

$\begin{array}{lll}4.26 & 1.65 & 0.74\end{array}$

$\begin{array}{lll}3.50 & 1.69 & 0.79\end{array}$

$\begin{array}{lll}3.99 & 1.74 & 0.84\end{array}$

$\begin{array}{lll}3.71 & 1.57 & 0.72\end{array}$

$19.82 \quad 6.25$

$87.82 \quad 13.26$

$5.92 \quad 1.16$

$\begin{array}{ll}5.79 & 1.27\end{array}$

0.82

0.89

$\begin{array}{lll}5.20 & 1.38 & 0.77\end{array}$

$\begin{array}{lll}5.82 & 1.25 & 0.92\end{array}$

$\begin{array}{lll}5.27 & 1.36 & 0.81\end{array}$

$\begin{array}{lll}4.88 & 1.52 & 0.68\end{array}$ 
was undertaken and results are shown in Table II. Not surprisingly each dimension of organizational commitment is correlated with the construct, but affective and continuance commitment have not been found to be correlated.

Each dimension of organizational commitment is correlated with the construct, with the exception of continuance commitment which is not significantly correlated with affective commitment. Continuance commitment is also not correlated with PEOU.

In order to test the hypothesis of this paper, two regressions were undertaken. The first involved using organizational commitment as the independent variable and PEOU as the dependent variable. Results provide support for this direct effect (with an $R^{2}=0.08 ; F=22.10, p<0.001$ and a standardised $\beta$ for organizational commitment of $0.27 ; p<0.01$ ). A second regression was performed to investigate the effect of each of the dimensions on PEOU. To do this regression scores were obtained from the factor analysis for the three dimensions so that the intercorrelations among dimensions as evidenced in Table II could be removed. These regression scores where then used as independent variables in a regression with PEOU as the independent variable. Results indicate that a significant relationship (adjusted $R^{2}=0.08 ; F=8.71, p<0.001$ ) with only two of the $\beta$ 's, for normative $(\beta=0.21 ; p<0.001)$ and affective commitment $(\beta=0.18 ; p<0.01)$, being significant, while continuance commitment was not found to have an effect. The significant $\beta$ values reported above indicate that normative commitment has a stronger effect than affective commitment on PEOU.

\section{Discussion, limitations and future research}

Many firms are incorporating technology into their marketing and operations (Meuter et al., 2005) and few people doubt the efficiency and effectiveness of such systems. Yet unless the people employing these systems feel comfortable enough to adopt and use them, they are ultimately of little use to organizations. A search within the IT systems implementation literature over the past decade would quickly reveal an astonishing number of would-be successful implementation stories turning into overnight failures. One of the major reasons behind this paradox is that while technical issues usually receive management's full attention, the people aspect is often neglected, to the extent that these ultimate service providers are regarded as dispensable. Consequently management discover, sometimes too late in the day, that users tend to avoid using these systems, preferring to do things their own way (Bird, 1995). Therefore the importance of identifying the conditions that foster the adoption and usage of such systems cannot be overstressed.

This paper has identified organizational commitment, specifically normative and affective commitment as having a positive effect on PEOU, whereas continuance commitment was not found to have any significant effect. Employees with high affective commitment develop a strong positive emotional bond toward their

\begin{tabular}{|c|c|c|c|c|c|c|}
\hline & $\mathrm{AC}$ & $\mathrm{CC}$ & $\mathrm{NC}$ & $\mathrm{OC}$ & PEOU & \\
\hline $\begin{array}{l}\text { Affective commitment (AC) } \\
\text { Continuance commitment }(\mathrm{CC}) \\
\text { Normative commitment }(\mathrm{NC}) \\
\text { Organizational commitment (OC) } \\
\text { Perceived ease of use (PEOU) }\end{array}$ & $\begin{array}{r}0.73 \\
-0.07 \\
0.20^{* *} \\
0.51^{* *} \\
0.27 * *\end{array}$ & $\begin{array}{l}0.74 \\
0.14^{*} \\
0.70^{* *} \\
0.05\end{array}$ & $\begin{array}{l}0.80 \\
0.65^{* *} \\
0.25^{* *}\end{array}$ & $\begin{array}{l}0.72 \\
0.27 * *\end{array}$ & 0.90 & $\begin{array}{r}\text { Table II. } \\
\text { Correlation among } \\
\text { dimensions and } \\
\text { constructs with } \\
\text { reliability } \alpha\end{array}$ \\
\hline Notes: $* * p<0.01 ; * p<0.05$ & & & & & & on diagonal \\
\hline
\end{tabular}

Perception of ease of use

357

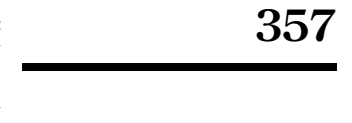


$\mathrm{JMD}$

32,4

358 organization (Allen and Meyer, 2000) and would therefore be more willing to put in an extra effort to overcome any perceptions of complexity related to the adoption and usage of technology within their organization. Normative commitment was found to have an even more pronounced effect on PEOU. A possible explanation could be that not only do individuals with high normative commitment develop a strong emotional attachment with their organization but they also foster a sense of obligation toward it (Allen and Meyer, 2000) which serves to augment their willingness to adopt and use technology. On the other hand, employees with continuance commitment have no emotional attachment or any sense of obligation to the organization, rather these individuals' bond with their organization is one of convenience, until they come across a better opportunity, which helps to explain why in their case, no significant effect was found between continuance commitment and PEOU.

The implications of these results are twofold. Given that PEOU is a key determinant of technology adoption (Davis, 1989; Venkatesh and Davis, 1996), understanding its antecedents and determinants is of paramount importance to researchers. This study has contributed to the existing literature by identifying organizational commitment, specifically the normative and affective commitment dimensions, as being important antecedents to PEOU. It also highlights the significance of the human aspect in determining whether technology implementation within organizations is a success story or an expensive failure. From a professional point of view, senior management should identify ways of fostering a sense of commitment toward the organization among employees, since those individuals who are affectively or normatively committed to their organization have been shown to exhibit a stronger will to try to overcome any barriers impeding their adoption and eventual use of technology.

The limitations of this paper include that only one bank was used in the study, raising questions as to whether the results apply to banks more generally. Given the intuitive and underlying theoretical link between the constructs, the findings are likely to be extendable to other banks and service firms. Like many studies this paper is also prone to specification error in that it is possible that other variables may also be influencing CRM adoption. It is therefore necessary to caution against oversimplification. It needs to be recognized that organizational commitment is a complex construct that interacts with various other constructs besides the outcome variable considered in this study. However, the adoption of a theory-based model should help to significantly mitigate this error. Another limitation worth considering is that since the questionnaire was sent out via the human resources department, participants may have felt some undue pressure from their institution and consequently may have answered in a way that they felt that their top management would have liked.

In terms of future research these results can be strengthened by considering a wider sample and the consideration of other variables. The latter could include confounding and antecedent variables such as complexity of an adopted CRM system, prior training provision, actual system utility and perceived benefits, perceptions of fairness or equity and inclination toward adoption of new technology. In addition there are various work-related variables, including proficiency, tenure, position and burnout, that are known to have an effect on organizational commitment (see Mathieu and Zajac, 1990). The study can also pave the way for other researchers to better investigate the role of organizational commitment in the technology adoption model which to date appears to have received scant attention. 


\section{References}

Agarwal, R. (2000), "Individual acceptance of information technologies", in Zmud, R.W. (Ed.), Framing the Domains of it Management: Projecting the Future From the Past, Pinnaflex Educational Resources, Cincinnati, OH, pp. 85-104.

Agarwal, R. and Prasad, J. (1999), "Are individual differences germane to the acceptance of new information technologies?”, Decision Sciences, Vol. 30 No. 2, pp. 361-391.

Allen, N.J. and Meyer, J.P. (1990), "The measurement and antecedents of affective, continuance, and normative commitment", Iournal of Occubational Psvchologv, Vol. 63 No. 1, pp. 1-18.

Allen, N.J. and Meyer, J.P. (1996), "Affective, continuance, and normative commitment to the organization: an examination of construct validity", Journal of Vocational Behavior, Vol. 49 No. 3, pp. 252-276.

Allen, N.J. and Meyer, J.P. (2000), "Construct validation in organizational behavior research: the case of organizational commitment", in Goffin, R.D. and Helmes, E. (Eds), Problems and Solutions in Human Assessment: Honoring Douglas N. Jackson at Seventv Kluwer Academic/Plenum Publishers, New York, NY, pp. 285-314.

Alper, E. (2008), “A trust-based approach to promote employees' openness to organizational change in Turkey", International Journal of Manpower, Vol. 29 No. 5, pp. 462-483.

Anandarajan, M., Igbaria, M. and Anakwe, U.P. (2002), "IT acceptance in a less developed country: a motivational factor perspective", International Iournal of Information Management, Vol. 22 No. 1, pp. 47-65.

Armenakis, A.A. and Bedeian, A.C. (1999), "Organizational change: a review of theory and research in the 1990's”, Journal of Management, Vol. 25 No. 3, pp. 216-293.

Bedard, J.C., Jackson, C., Ettredge, M.L. and Johnstone, K.M. (2003), "The effect of training on auditors' acceptance of an electronic work system", International Iournal of Accounting Information Svstems, Vol. 4 No. 4, pp. 227-250.

Berry, L.L. (1983), "Relationship marketing”, in Berry, L.L., Shostack, G.L. and Upah, G.D. (Eds), Perspectives on Services, Marketing, American Marketing Association, Chicago, IL, pp. 25-28.

Bird, J. (1995), "UK: Getting IT right from the start", Management Today, available at: www. managementtoday.co.uk/news/410123/UK-GETTING-RIGHT-START/?DCMP = ILCSEARCH (accessed March 28, 2011).

Brief, A.P. and Weiss, H.M. (2002), "Organizational behavior: affect in the workplace", Annual Review of Psvchologv Vol. 53 No. 1, pp. 279-307.

Carr, N.G. (2003), “IT doesn't matter”, Harvard Business Review, Vol. 81 No. 5, pp. 41-50.

Chau, P.Y.K. and Hu, P.J. (2002), "Examining a model of information technology acceptance by individual professionals: an exploratory study", Journal of Management Information Systems, Vol. 18 No. 4, pp. 191-229.

Chen, I.J. and Popovich, K. (2003), "Understanding customer relationship management (CRM): people, process and technology", Business Process Management Iournal, Vol. 9 No. 5, pp. $672-688$.

Choi, J.N. (2006), "Multilevel and cross-level effects of workplace attitudes and group member relations on interpersonal helping behavior", Human Performance, Vol. 19 No. 4, pp. 383-402.

Christopher, M., Payne, A. and Ballantyne, D. (1991), Relationship Marketing, ButterworthHeinemann, Oxford.

Davis, F.D. (1989), "Perceived usefulness, perceived ease of use and user acceptance", MIS Quarterlv, Vol. 13 No. 3, pp. 319-340.
Perception of ease of use

359 
$\mathrm{JMD}$

32,4

360
Davis, F.D., Bagozzi, R.P. and Warshaw, P. (1989), "User acceptance of computer technology: a comparison of two theoretical models", Management Science, Vol. 35 No. 8, pp. 982-1003.

Gefen, D. and Straub, D. (2000), "The relative importance of perceived ease of use in IS adoption: a study of E-commerce adoption", Journal of the Association for Information Systems, Vol. 1 No. 8, pp. 1-30.

Ghorab, K.E. (1997), "The impact of technology acceptance considerations on system usage and adopted level of technological sophistication: an empirical investigation", International Iournal of Information Management, Vol. 17 No. 4, pp. 249-259.

Grönroos, C. (1994), "From marketing mix to relationship marketing: toward a paradigm shift in marketing”, Asia-Australia Marketing Iournal, Vol. 2 No. 1, pp. 9-30.

Hopkins, J. and Kessler, M. (2002), “Companies squander billions on tech”, USA Today, available at: www.usatoday.com/usatonline/200205020/4124243 s.htm (accessed March 28, 2011).

Hu, P.J., Chau, P.Y.K., Sheng, O.R.L. and Tam, K.Y. (1999), "Examining the technology acceptance model using physician acceptance of telemedicine technology", Journal of Management Information Systems, Vol. 16 No. 2, pp. 91-112.

Jackson, B.B. (1985), "Building customer relationships that last", Harvard Business Review, Vol. 63 No. 6, pp. 120-128.

Jackson, C.M., Chow, S. and Leitch, R.A. (1997), "Toward an understanding of the behavioral intention to use an information system”, Decision Sciences, Vol. 28 No. 2, pp. 357-389.

Karahanna, E. and Straub, D.W. (1999), "The psychological origins of perceived usefulness and ease-of-use", Information and Management, Vol. 35 No. 4, pp. 237-250.

Kimiloglu, H. and Zarali, H. (2009), "What signifies success in eCRM?", Marketing Intelligence and Planning, Vol. 27 No. 2, pp. 246-267.

Liao, C.H. and Tsou, C.W. (2009), "User acceptance of computer-mediated communication: the skype out case", Expert Systems With Applications, Vol. 36 No. 3, Part 1, pp. 4595-4603.

Magni, M. and Pennarola, F. (2005), "Stand by me: the quality of intra-organizational relationships as antecedent of IT adoption”, ECIS (2005) Proceedings, Paper No. 76, available at: http://aisel.aisnet.org/ecis2005/76 (accessed March 28, 2011).

Magni, M. and Pennarola, F. (2008), "Intra-organizational relationships and technology acceptance", International Iournal of Information Management, Vol. 28 No. 6, pp. 517-523.

Mathieu, J.E. and Zajac, D.M. (1990), “A review and meta-analysis of the antecedents, correlates, and consequences of organizational commitment”, Psychological Bulletin, Vol. 108 No. 2, pp. 171-194.

Meuter, M.L., Bitner, M.J., Ostrom, A.L. and Brown, S.W. (2005), "Choosing among alternative service delivery models: an investigation of customer trial of self-service technologies", Iournal of Marketing, Vol. 69 No. 2, pp. 61-83.

Meyer, J., Allen, N. and Smith, C. (1993), "Commitment to organizations and occupations: extension and test of a three-component conceptualization", Iournal of Applied Psvchologv, Vol. 78 No. 4, pp. 538-551.

Meyer, J.P. and Allen, N.J. (1984), “Testing the 'side-bet theory' of organizational commitment: some methodological considerations", Iournal of Applied Psychology Vol. 69 No. 3, pp. 372-378.

Meyer, J.P. and Allen, N.J. (1991), "A three-component conceptualization of organizational commitment”, Human Resource Management Review, Vol. 1 No. 1, pp. 61-89. 
Meyer, J.P. and Allen, N.J. (1997), Commitment in the Workplace: Theory, Research, and Application, Sage Publications, Thousand Oaks, CA.

Meyer, J.P., Stanley, D.J., Herscovitch, L. and Topolnytsky, L. (2002), “Affective, continuance, and normative commitment to the organization: a meta-analysis of antecedents, correlates, and consequences", Journal of Vocational Behavior, Vol. 61 No. 1, pp. 20-52.

Moon, J.W. and Kim, Y.G. (2001), "Extending the TAM for the world-wide-web context", Information and Management, Vol. 38 No. 4, pp. 217-230.

Moore, G.C. and Benbasat, I. (1991), "Development of an instrument to measure the perceptions of adopting an information technology innovation", Information Svstems Research, Vol. 2 No. 3, pp. 192-222.

Nov, O. and Ye, C. (2008), "Users' personality and perceived ease of use of digital libraries: the case for resistance to change", Iournal of The American Society for Information Science and Technology, Vol. 59 No. 5, pp. 845-851.

Nunnally, J.C. (1967), Psychometric Theory, McGraw-Hill, New York, NY.

Pennington, R.R., Kelton, A.S. and DeVries, D.D. (2006), "The effects of qualitative overload on technology acceptance”, Iournal of Information Sustems, Vol. 20 No. 2, pp. 25-36.

Schneider, B. and Bowen, D.E. (1995), Winning the Service Game, Harvard Business School Press, Boston, MA.

Smith, M. and Chang, C. (2010), "Improving customer outcomes through the implementation of customer relationship management", Asian Review of Accounting, Vol. 18 No. 3, pp. 260-285.

Torkzadeh, G. and Lee, J. (2003), "Measures of perceived end-user computing skills", Information and Management, Vol. 40 No. 7, pp. 607-615.

Venkatesh, V. (1999), "Creation of favorable user perceptions: exploring the role of intrinsic motivation”, MIS Quarterly, Vol. 23 No. 2, pp. 239-260.

Venkatesh, V. (2000), "Determinants of perceived ease of use: integrating control, intrinsic motivation, and emotion into the technology acceptance model", Information Svstems Research, Vol. 11 No. 4, pp. 342-365.

Venkatesh, V. and Davis, F.D. (1996), "A model of the antecedents of perceived ease of use: development and test”, Decision Sciences, Vol. 27 No. 3, pp. 451-481.

Venkatesh, V. and Davis, F.D. (2000), "A theoretical extension of the technology acceptance model: four longitudinal field studies”, Management Science, Vol. 46 No. 2, pp. 186-204.

Venkatesh, V. and Morris, M.G. (2000), "Why don't men ever stop to ask for directions? Gender, social influence, and their role in technology acceptance and usage behavior", MIS Quarterly, Vol. 24 No. 1, pp. 115-139.

Venkatesh, V., Morris, M.C., Davis, C.B. and Davis, F.D. (2003), "User acceptance of information technology: towards a unified view”, MIS Quarterly, Vol. 27 No. 3, pp. 425-478.

Yousafzai, S.Y., Foxall, G.R. and Pallister, J.G. (2007), "Technology acceptance: a meta-analysis of the TAM: part 1", Journal of Modeling in Management, Vol. 2 No. 3, pp. 251-280.

\section{Further reading}

Schneider, B. and Bowen, D.E. (1993), "The service organization: human resources management is crucial", Organizational Dynamics, Vol. 21 No. 4, pp. 39-52.

\section{About the authors}

Joseph Vella is a doctoral student at Luleå University of Technology in Luleå, Sweden and has been a managing director of his own company for a number of years. Joseph Vella is the corresponding author and can be contacted at: joseph.vella@ltu.se
Perception of ease of use

361 
JMD 32,4

362

Albert Caruana is Professor of Marketing at the University of Malta, Malta. His work includes papers in the Journal of Advertising, Journal of Business Research, Industrial Marketing Management and the European Journal of Marketing.

Leyland Pitt is Professor of Marketing at Segal Graduate School of Business, Simon Fraser University, Vancouver, Canada and is Senior Research Fellow at Leeds University Business School in the UK. His work has been accepted for publication by such journals as the Journal of Advertising, Information Systems Research, Journal of the Academy of Marketing Science, Sloan Management Review, Business Horizons, California Management Review, Communications of the $A C M$ and MIS Quarterly (which he also served as Associate Editor).

To purchase reprints of this article please e-mail: reprints@emeraldinsight.com Or visit our web site for further details: www.emeraldinsight.com/reprints 